Mini-review

\title{
Skin tumors and their viral origin
}

\author{
Ramona Gabriela Ursu*, Luminița Smaranda lancu \\ Microbiology Department, “Grigore T. Popa” University of Medicine and Pharmacy, lași, Romania
}

\begin{abstract}
Cutaneous tumors have risk factors, including oncogenic viruses. In this paper, the most frequent viruses known to be related to skin tumors, the available diagnostic detection assays and possible prevention and therapy are presented. The clinical utility of this report is to raise awareness to the fact that some cancer-inducing viruses may be treated with targeted therapy and some other infections can be prevented by vaccination.

Keywords: MCPyV; cutaneous HPV types; herpesviruses; skin cancer; virus-induced
\end{abstract}

\section{Introduction}

The International Agency for Research on Cancer (IARC) estimated that $15-20 \%$ of cancers are associated with infectious agents [1]. Around $12 \%$ of cancers are causally linked to 7 viruses: Epstein-Barr virus (EBV), hepatitis $B$ virus (HBV), human papillomavirus (HPV), human T-cell lymphotropic virus (HTLV), hepatitis C virus (HCV), Kaposi's sarcoma herpesvirus (KSHV), and Merkel cell polyomavirus (MCPyV) [2]. The abovementioned viruses belong to Polyomaviridae, Papillomaviridae,

Herpesviridae,

Hepadnaviridae, Flaviviridae families and represent the research subject for many authors, mainly regarding their life-cycle into the host cell and the risk factors which lead to tumor transformation [3].

The recent IARC publication (September 2018) - the WHO Classification of Skin Tumors contains data regarding diagnostic criteria, pathological features, genetic and other associated molecular alterations, prognosis, and protective factors for each of the tumor

Received: July 2018; Accepted after review: September 2018; Published: September 2018.

${ }^{*}$ Corresponding author: Ramona Gabriela Ursu, Microbiology Department, "Grigore T. Popa" University of Medicine and Pharmacy, 16 Universitatii str, Iasi, Romania.

Email: ramona.ursu@umfiasi.ro types covered. Skin tumors have risk factors (e.g., sun susceptibility and/or exposure). The TNM classification of skin tumors includes certain types which are viral correlated, e.g., Merkel cell carcinoma of skin, skin carcinoma of the head and neck, and EBV-positive mucocutaneous ulcer [4].

GLOBOCAN rates Romania on $7^{\text {th }}$ place in Central and Eastern Europe regarding incidence of all non-melanoma skin cancer and Kaposi sarcoma (male incidence 274.9 versus 81.5 female incidence, per 100000 all ages). The percentage of melanoma cases in 2012, attributable to ultraviolet (UV) radiation exposure was 68.8 for men and 44.3 for women, all ages (30+ years) [5].

\section{Oncogenic viruses and their potential role in skin cancer}

Polyomaviruses: Recent sensitive molecular assays, like next generation sequencing, have led to the discovery of 10 human polyomaviruses (HPyVs): BKV, KIV, JCV, MCV, WUV, TSV, HPyV6, HPyV7, HPyV9, and SV40. Merkel cell carcinoma (MCC), produced by MCV (Merkel cell polyomavirus) is known as a rare skin tumor which can have an aggressive clinical evolution with an unfavorable prognosis. The incidence of this cancer has increased lately, 
year by year in USA [6]. Recent studies had detected BKV DNA in $18.5 \%$ of patients with oral squamous cell carcinoma (OSCC) [7]. Also, increasing evidence links BKPyV to HIVassociated salivary gland disease [8].

Herpesviruses: Two members of the herpesvirus family, Epstein-Barr virus (EBV) and Kaposi's sarcoma herpes virus (KSHV) have been shown to be, at least partially, responsible for cancer in humans. EBV appears to be the causative agent for Burkitt lymphoma and is associated with other lymphoproliferative diseases such as Hodgkin lymphoma and nasopharyngeal carcinoma [3]. EBV/DNA was detected in oral squamous cell carcinoma in proportion of $16.66 \%$ [9], and other authors found EBV in $57.5 \%$, HHV-1 in $7.5 \%$, and $\mathrm{CMV}$ in $10 \%$ of patients [10].

Cutaneous beta papilloma viruses' types: The beta HPV types (HPV 5, 8, 9, 12, $14,15,17,19,20,21,22,23,24,25,36,37$, $38,47,49,75,76,80,92,93$, and 96) are originally isolated in non-melanoma skin cancer (NMSC) of individuals with a rare genetic disorder called Epidermodysplasia Verruciformis. Immunosuppressed organ transplant recipients have a 50-100-fold increased risk of developing NMSC compared to the general population. DNA from several beta HPV types were detected in skin cancers in immunosuppressed patients. The antibodies titer against some beta HPV types was observed to be higher in patients with cutaneous SCC in comparison with controls. Only E6 and E7 of a few beta HPV types immortalize primary keratinocytes: HPV 37 , 38, 49, 76, but not HPV 14, 24, 36, 100, 120 and 122. The role in carcinogenesis was demonstrated by beta HPV 38, 49 which inactivates $\mathrm{pRb}$ and $\mathrm{p} 53$ functions; HPV $49 \mathrm{E} 6$ and $\mathrm{E} 7$ shares some proteins with HPV 16 and E7; HPV 16 and HPV 49 induce p16INK4a accumulation. Transforming activities of HPV 8, 38 and HPV 49 were demonstrated in an in vivo model. Beta HPV may contribute to the initiation but not the maintenance of SCC, being one co-factor that could enhance the carcinogenetic potential of UV damage [11].

\section{Molecular assays used for detection of oncogenic viruses}

Oncogenic viruses are not detected by routine tests in local laboratories. Nowadays there are many commercially available detections kits. In order to be clinically efficient, one should know which assay to choose for detection of these viruses in tumor samples. The lab assays should fulfill some criteria (e.g., sensitivity, specificity, positive and negative predictive values) to be able then to confirm the diagnosis and to optimize therapy, if possible. Keywords/terms for searching scientific literature on PubMed regarding oncogenic viruses' involvement in skin tumors: „polyomaviruses/cutaneous HPV types/ herpesviruses AND skin tumors" for the last 5 years, retrieved 192 articles for polyomaviruses, 41 for cutaneous HPV types and 7 for herpesviruses, which is suggestive of the huge involvement of MCPyV in skin carcinogenesis. Table 1 lists the majority of the assay used in 2017-2018 for MCPyV as molecular assays, based on different types of PCR and a few of the immunohistochemistry assays. For HPV cutaneous types we identified studies performed in very well-known research centers (e.g. IARC, France; DKFZ, Germany) equipped for this high level of research. Table 2 lists the cutaneous HPV types detected in associations with skin cancers.

\section{Inclusion criteria for skin cancer-inducing viruses}

Inclusion criteria for viruses inducing skin cancer are established after evaluating the type of study (cohort or case-control), quality of the analyzed studies, temporal effects, use of biomarkers in epidemiological studies, criteria for causality and studies of cancer in experimental animals. Also important are the toxicokinetic data, information regarding mechanisms of carcinogenesis, functional changes at the cellular and molecular level [27]. 
Table 1. Laboratory assays used for MCPyV in skin tumors [12-21]

\begin{tabular}{|c|c|c|c|}
\hline $\begin{array}{l}\text { AUTHOR, YEAR OF } \\
\text { PUBLICATION }\end{array}$ & COUNTRY & ASSAY & CONCLUSIONS \\
\hline Murakami I, 2018 & Japan & $\begin{array}{l}\text { Quantitative PCR for } \\
\text { MCPyV-DNA, } \\
\text { proteomics, } \\
\text { immunohistochemistry } \\
\text { IL-17 }\end{array}$ & $\begin{array}{l}\text { MCPyV was established as a causal } \\
\text { agent in tested tumors }\end{array}$ \\
\hline Konstatinell A, 2018 & Norway & MicroRNAs & $\begin{array}{l}\text { MicroRNAs was considered as a } \\
\text { biomarker for the diagnosis, } \\
\text { progression and prognosis, and } \\
\text { treatment of MCC }\end{array}$ \\
\hline Kervarrec T, 2018 & France & $\begin{array}{l}\text { Multiplex genotyping } \\
\text { assay }\end{array}$ & $\begin{array}{l}\text { Half of the combined MCC cases were } \\
\text { positive for MCPyV }\end{array}$ \\
\hline Vandeven N, 2018 & $\begin{array}{l}\text { Washington } \\
\text { USA }\end{array}$ & $\begin{array}{l}\text { Whole-exome sequence } \\
\text { data }\end{array}$ & $\begin{array}{l}\text { Stronger underlying immunity against } \\
\text { MCC contributes to primary lesion } \\
\text { elimination and improved survival }\end{array}$ \\
\hline Li L, 2018 & $\begin{array}{l}\text { Texax, } \\
\text { SUA }\end{array}$ & $\begin{array}{l}\text { Immunohistochemistry in } \\
\text { a fine needle aspirate }\end{array}$ & $\begin{array}{l}\text { The tumor cells were positive with pan } \\
\text { cytokeratin AE1/AE3, CK20, CD56, } \\
\text { synaptophysin, chromogranin, and } \\
\text { MCPyV }\end{array}$ \\
\hline $\begin{array}{l}\text { Álvarez-Argüelles ME, } \\
2017\end{array}$ & Spain & $\begin{array}{l}\text { Quantitative Real-Time- } \\
\text { PCR (qRT-PCR) in FFPE } \\
\text { MCC }\end{array}$ & $\begin{array}{l}\text { The amplification techniques are easily } \\
\text { applied and suitable for detecting the } \\
\text { presence of MCPyV }\end{array}$ \\
\hline Kuromi T, 2017 & Japan & $\begin{array}{l}\text { Immunohistochemistry } \\
\text { for hedgehog signaling } \\
\text { (SHH, IHH, PTCH1, } \\
\text { SMO, GLI1, GLI2, } \\
\text { Polymerase chain } \\
\text { reaction and sequence } \\
\text { analysis for SHH and } \\
\text { GLI1 exons }\end{array}$ & $\begin{array}{l}\text { Expression of SHH and GLI1 may be } \\
\text { useful prognostic markers of MCC }\end{array}$ \\
\hline Wang L, 2017 & $\begin{array}{l}\text { Michigan, } \\
\text { SUA }\end{array}$ & $\begin{array}{l}\text { RNAscope, an RNA in } \\
\text { situ hybridization (ISH) } \\
\text { assay for detection of } \\
\text { RNA transcripts in } \\
\text { tissues } \\
\text { qPCR for comparison }\end{array}$ & $\begin{array}{l}\text { A strong correlation between qPCR } \\
\text { copy number and RNA-ISH product } \\
\text { score } \\
\text { RNA-ISH is comparably sensitive to } \\
\text { qPCR for detection of MCPyV and } \\
\text { allows for correlation with tissue } \\
\text { morphology. }\end{array}$ \\
\hline Arvia R, 2017 & Italy & $\begin{array}{l}\text { qPCR and ddPCR for } \\
\text { MCPyV detection and } \\
\text { quantification in FFPE } \\
\text { tissue samples. }\end{array}$ & $\begin{array}{l}\text { The ddPCR represents a better method } \\
\text { for detection of MCPyV in FFPE } \\
\text { biopsies }\end{array}$ \\
\hline Harms KL, 2017 & $\begin{array}{l}\text { Michigan, } \\
\text { USA }\end{array}$ & $\begin{array}{l}\text { Next-generation } \\
\text { sequencing }\end{array}$ & $\begin{array}{l}\text { Next-generation sequencing analysis of } \\
\text { chromosomal copy number changes } \\
\text { and mutations is useful in distinguishing } \\
\text { multiple primary MCCs }\end{array}$ \\
\hline
\end{tabular}


Table 2. Cutaneous HPV types detected in skin cancers by different assays [22-26]

\begin{tabular}{|c|c|c|c|}
\hline $\begin{array}{l}\text { AUTHOR, YEAR OF } \\
\text { PUBLICATION }\end{array}$ & COUNTRY & ASSAY & $\begin{array}{l}\text { HPV types involved in skin } \\
\text { cancers }\end{array}$ \\
\hline Viarisio D, 2018 & Germany & $\begin{array}{l}\text { Mouse model that expresses } \\
\text { beta HPV38 E6 and E7 } \\
\text { whole-exome sequencing }\end{array}$ & $\begin{array}{l}\text { Beta HPV type (e.g., HPV } \\
\text { 38) act only at an initial stage } \\
\text { of carcinogenesis }\end{array}$ \\
\hline Faust H, 2016 & Sweden & IgG to pseudovirions & $\begin{array}{l}16 \text { different HPV types }(3,5 \text {, } \\
6,11,15,16,18,31,32,33 \text {, } \\
38,45,52,58,68 \text {, and } 76)\end{array}$ \\
\hline Arroyo Mühr LS, 2015 & Sweden & Whole genome amplified DNA & HPV197 \\
\hline Shterzer N, 2014 & Israel & $\begin{array}{l}\text { Vaccinogenic abilities in primary } \\
\text { human keratinocytes (PHKs) }\end{array}$ & HPV types 10, 49 and 38, \\
\hline Bzhalava D, 2014 & Sweden & Metagenomic deep sequencing & $\begin{array}{l}396 \text { different HPV types in } \\
\text { human skin }\end{array}$ \\
\hline
\end{tabular}

In order to label a virus as causal factor in tumorigenesis, objective criteria of diagnosis are necessary. For example, to conclude that an MCV is the etiological factor in a FFPE tumor samples, it is necessary to get a very high signal by MagPix detection, in comparison with controls (unpublished personal data). The reason for this is that polyomaviruses can be part of normal flora and only the simple detection of DNA is not enough to establish the diagnosis. For HPV HNC driven cases there are also criteria for establishing diagnosis (some authors have published an algorithm of diagnosis which included three biomarkers - DNA, RNA, p16INK4a of HPV [28], while others used only the last two biomarkers) [29, 30]. In some fresh skin and HNC tumors we have detected by multiplex genotyping the DNA of some polyoma and herpesviruses (EBV, $\mathrm{HH}$, HH8, MCV - unpublished personal data), but for the moment we cannot conclude that these viruses are causally-related with the analyzed tumors. Further on, this paper is referring to other tumors which could be oncogenic viruses related, e.g. malignant melanoma, sarcoma, other soft tissues tumors.

Melanoma of skin is mentioned by GLOBOCAN with a 5-year prevalence of 18 in adult Romanian men and 20 in women, occupying the last place of the first 20
European countries (after countries like Germany, with a male incidence of 342 , UK 274, France - 187, Sweden - 61) [5]. This report raises the question of whether the official data regarding this type of cancer is correctly performed in our country, or maybe there are different risk factors for this cancer. WHO mentions that the main risk factors for malignant melanoma are the skin type, the number of nevi, and exposure to solar UV [31].

We sought to review the scientific literature to see if there are publications which detected oncogenic viruses in malignant melanoma (MM). From 26 studies identified in PubMed using the key words "polyomaviruses malignant melanoma", one paper published the results of testing samples of primary malignant melanoma for polyomaviruses. Ramqvist $\mathrm{T}$ et al tested $57 \mathrm{MM}$ samples by sensitive assay Luminex multiplex genotyping for $10 \mathrm{HPyVs}$ and none of these DNA viruses were detected. The authors concluded that these viruses don't have any role in development of this kind of tumor [32]. Interestingly, a few other articles detected polyomaviruses in induced cutaneous squamous cell carcinoma in patients with $\mathrm{MM}$ after therapy with BRAF inhibitors (e.g., vemurafenib) [33-35]. Regarding cutaneous HPV types and herpesviruses, the PubMed search did not find any study that detected 
these viruses being involved in development of MM.

Kaposi sarcoma in adults is the most frequent in Italy and Spain. Romania is not among the first 20 countries in Europe regarding the prevalence of this cancer. Still, Romania can be found on the $7^{\text {th }}$ place in Central and Eastern Europe, after Russian Federation, Hungary, Poland, but with no mentioned values for incidence and prevalence [5].

First time detected in Kaposi sarcomas associated with AIDS, this virus was coined Kaposi sarcoma-associated herpesvirus (KSHV), also known as human herpesvirus 8 (HHV-8) [27].

$\mathrm{KSHV}$ is known to be involved in Kaposi sarcoma (supported by 22 cohort studies and 80 case-control studies - all showing broadly consistent evidence of an association between KSHV infection and Kaposi sarcoma), primary effusion lymphoma, multicentric Castleman disease, multiple myeloma [27]. HHV-8 is frequently associated with immunosuppression no matter the cause (iatrogenic, viral or agerelated) [36]. This feature explains the presence of this virus post-transplant (e.g., heart and kidney transplantation) [37, 38].

Following the same model used for MM, we searched PubMed for oncogenic viruses' involvement in sarcoma; there was a double viral infection presence of Beta papillomavirus in Kaposi sarcoma lesions [39]. Other interesting associations were detected between MCC and Langerhans cell sarcoma tissues [40] and during treatment with superpotent topical steroids and methotrexate for bullous pemphigoid [41].

Soft tissue tumors: regarding oncogenic viruses' involvement in soft tissues tumors, EBV is mentioned as primary Epstein-Barr virus-positive large B-cell lymphoma mainly affecting the lumina of the aorta [42], and bilateral psoas muscle lymphoma [43]. Also, HHV-8 was detected on multiple, erythematous to purple tumors, located on areas of post-mastectomy lymphedema [44]. EBV-associated tumors are recognized by IARC to be involved in Lymphoepithelioma-like carcinoma with $>80 \%$ positivity [27].

\section{Therapy and available prevention of these viruses-induced tumors}

The classical therapy of skin tumors is surgical radical excision, followed by radioand chemotherapy.

The main prevention method of tumor induced viruses is by vaccination [45]. The example of HPV vaccine is illustrative. From the bivalent HPV vaccine in 2014 the Food and Drug Administration (FDA) approved the 9 vHPV which prevent infections with HPV types $16 / 18 / 31 / 33 / 45 / 52 / 58$, as well as genital warts related to HPV types 6 and 11 [46]. Moreover, therapeutic HPV vaccines are in discussion [47]. There are studies about future vaccines which could prevent skin cancers induced by HPV cutaneous types [48, 49]. Another novel cancer therapy recently revealed that Oncolytic Viruses (OV) have a peculiar replication life cycle, by replicating only in cancer cells and not in healthy tissue. In addition to this direct oncolytic activity, OVs have a double effect, leading to the appearance of antibodies against the virus itself and also against the cancer tissue. These OVs can use both DNA and RNA viruses and require much care regarding monitoring the efficiency of this therapy [50, 51]. Even though there is no known oncogenic virus involvement in $\mathrm{MM}$, there is an interesting therapy with the help of a herpesvirus, a DNA virus harboring the capacity to establish lifelong latent-recurrent infections. Recently, patients with melanoma that were not resected surgically were treated with Talimogene laherparepvec (T-VEC). TVEC contains an oncolytic herpesvirus type 1 which is known to produce granulocyte macrophage colony-stimulating factor (GMCSF) during its intratumoral replication [5254].

Recent studies published data which support the anti-PD-L1 antibody - Avelumab's approval in the United States and European Union and use as a standard-of-care treatment for metastatic MCC $[55,56]$. Detecting the virus presence in a tumor could optimize targeted therapy, such as RB1 tumorsuppressor or NVP-BEZ235, a dual $\mathrm{PI3K} / \mathrm{mTOR}$ inhibitor $[57,58]$. 


\section{Conclusion}

The clinical utility of this mini-review is to emphasize that certain tumors are virusinduced. Diagnosing these tumors requires reliable criteria for involving viruses as etiologic agents through sensitive molecular biology assays. Further research is needed in order to find specific therapy (e.g., oncolytic

\section{References}

1. Stewart BW, Wild CP. World Cancer Report 2014. Lyon, France: International Agency for Research on Cancer, 2014.

2. White MK, Pagano JS, Khalili K. Viruses and human cancers: a long road of discovery of molecular paradigms. Clin Microbiol Rev 2014; 27(3):463-481.

3. Milavetz $\mathrm{BI}$, Balakrishnan L. Viral epigenetics. Methods Mol Biol 2015; 1238:569-596.

4. Elder DE, Massi D, Scolyer RA, Willemze R. WHO Classification of Skin Tumors, 4th Edition, IARC Press Lyon, 2018.

5. Ferlay J, Soerjomataram I, Ervik M, et al. GLOBOCAN 2012 v1.0, Cancer Incidence and Mortality Worldwide: IARC Cancer Base No.11. Lyon, France: International Agency for Research on Cancer; 2013. [http://gco.iarc.fr/ available at 09.23.2018].

6. Saini AT, Miles BA. Merkel cell carcinoma of the head and neck: pathogenesis, current and emerging treatment options. Onco Targets Ther 2015; 8:2157-2167.

7. Polz D, Morshed K, Stec A, Podsiadło Ł, PolzDacewicz M. Do polyomavirus hominis strains $\mathrm{BK}$ and JC play a role in oral squamous cell carcinoma? Ann Agric Environ Med 2015; 22(1):106-109.

8. Burger-Calderon $\mathrm{R}$, Webster-Cyriaque $\mathrm{J}$. Human BK Polyomavirus-The Potential for head and neck malignancy and disease. Cancers (Basel) 2015; 7(3):1244-1270.

9. Bussu F, Sali M, Gallus R, et al. HPV and EBV Infections in neck metastases from occult primary squamous cell carcinoma: Another Virus-related neoplastic disease in the head and neck region. Ann Surg Oncol 2015; 22(suppl 3):S979-984.

10. Polz-Gruszka D, Stec A, Dworzański J, PolzDacewicz M. EBV, HSV, CMV and HPV in laryngeal and oropharyngeal carcinoma in Polish patients. Anticancer Res 2015; 35(3):1657-1661. viruses, gene targeted therapy, therapeutic vaccination) or oncologic prevention by classical vaccines.

\section{Acknowledgements}

RGU was funded by "Grigore T. Popa" University of Medicine and Pharmacy lasi, based on contract no. 30336 / 28.12.2017.

11. Accardi R, Gheit T. Cutaneous HPV and skin cancer. Presse Med 2014; 43(12Pt2):e435443.

12. Murakami I, Wada $\mathrm{N}$, Nakashima $\mathrm{J}$, et al. Merkel cell polyomavirus and Langerhans cell neoplasm. Cell Commun Signal 2018; 16(1):49.

13. Konstatinell $A$, Coucheron $D H$, Sveinbjørnsson $B$, Moens U. MicroRNAs as potential biomarkers in Merkel cell carcinoma. Int $\mathrm{J} \mathrm{Mol}$ Sci 2018; 19(7). pii: E1873.

14. Kervarrec T, Samimi M, Gaboriaud $P$, et al. Detection of the Merkel cell polyomavirus in the neuroendocrine component of combined Merkel cell carcinoma. Virchows Arch 2018; 472(5):825-837.

15. Vandeven $\mathrm{N}$, Lewis $\mathrm{CW}$, Makarov $\mathrm{V}$, et al. Merkel cell carcinoma patients presenting without a primary lesion have elevated markers of immunity, higher tumor mutation burden, and improved survival. Clin Cancer Res 2018; 24(4):963-971.

16. Li L, Molberg K, Cheedella N, Thibodeaux J, Hinson S, Lucas E. The diagnostic utility of Merkel cell polyomavirus immunohistochemistry in a fine needle aspirate of metastatic Merkel cell carcinoma of unknown primary to the pancreas. Diagn Cytopathol 2018; 46(1):67-71.

17. Álvarez-Argüelles ME, Melón S, Rojo S' et al' Detection and quantification of Merkel cell polyomavirus. Analysis of Merkel cell carcinoma cases from 1977 to 2015. J Med Virol 2017; 89(12):2224-2229.

18. Kuromi $T$, Matsushita $M$, Iwasaki $T$, et al. Association of expression of the hedgehog signal with Merkel cell polyomavirus infection and prognosis of Merkel cell carcinoma. Hum Pathol 2017; 69:8-14.

19. Wang L, Harms PW, Palanisamy N, et al. Age and gender associations of virus positivity in Merkel cell carcinoma characterized using a novel RNA In Situ hybridization assay. Clin Cancer Res 2017; 23(18):5622-5630. 
20. Arvia R, Sollai M, Pierucci F, Urso C, Massi D, Zakrzewska K. Droplet digital PCR (ddPCR) vs quantitative real-time PCR (qPCR) approach for detection and quantification of Merkel cell polyomavirus (MCPyV) DNA in formalin fixed paraffin embedded (FFPE) cutaneous biopsies. $J$ Virol Methods 2017; 246:15-20.

21. Harms KL, Lazo de la Vega L, Hovelson DH,'et al. Molecular profiling of multiple primary Merkel cell carcinoma to distinguish genetically distinct tumors from clonally related metastases. JAMA Dermatol 2017; 153(6):505512.

22. Viarisio D, Müller-Decker $K$, Accardi $R$,' et al. Beta HPV38 oncoproteins act with a hit-andrun mechanism in ultraviolet radiation-induced skin carcinogenesis in mice. PLoS Pathog 2018; 14(1):e1006783.

23. Faust $H$, Andersson $K$, Luostarinen $T$, Gislefoss RE, Dillner J. Cutaneous human Papillomaviruses and squamous cell carcinoma of the skin: nested case-control study. Cancer Epidemiol Biomarkers Prev 2016; 25(4):721724.

24. Arroyo Mühr LS, Hultin E, Bzhalava D, et al. Human papillomavirus type 197 is commonly present in skin tumors. Int $J$ Cancer 2015; 136(11):2546-2555.

25. Shterzer N, Heyman D, Shapiro B, et al. Human papillomavirus types detected in skin warts and cancer differ in their transforming properties but commonly counteract UVB induced protective responses in human keratinocytes. Virology 2014; 468-470:647-659.

26. Bzhalava D, Mühr LS, Lagheden C, Ekström J, Forslund O, Dillner J, Hultin E. Deep sequencing extends the diversity of human papillomaviruses in human skin. Sci Rep 2014; 4:5807.

27. IARC Working Group: Evaluation of Carcinogenic Risks to Humans II. A review of human carcinogens. Part B: Biological agents (IARC monographs on the evaluation of carcinogenic risks to humans; v. 100B), IARC Press Lyon, 2009.

28. Ursu RG, Danciu M, Spiridon IA, et al. Role of mucosal high-risk human papillomavirus types in head and neck cancers in Romania. PLoS One 2018; 13(6):e0199663.

29. Bersani C, Haeggblom L, Ursu RG, et al. Overexpression of FGFR3 in HPV-positive tonsillar and base of tongue cancer is correlated to outcome. Anticancer Res 2018; 38(8):4683-4690.

30. Haeggblom L, Ursu RG, Mirzaie L, et al. No evidence for human papillomavirus having a causal role in salivary gland tumors. Diagn Pathol 2018; 13(1):44.
31. WHO: Health effects of UV radiation [http://www.who.int/uv/health/uv_health2/en/ind ex1.html available at 09.23.2018]

32. Ramqvist $T$, Nordfors $C$, Dalianis $T$, Ragnarsson-Olding $B$. DNA from human polyomaviruses, TSPyV, MWPyV, HPyV6, 7 and 9 was not detected in primary mucosal melanomas. Anticancer Res 2014; 34(2):639643.

33. Schrama D, Groesser L, Ugurel S, et al. Presence of human polyomavirus 6 in mutation-specific BRAF inhibitor-induced epithelial proliferations. JAMA Dermatol 2014; 150(11):1180-1186.

34. Purdie KJ, Proby CM, Rizvi H, et al. The role of human Papillomaviruses and Polyomaviruses in BRAF-inhibitor induced cutaneous squamous cell carcinoma and benign squamoproliferative lesions. Front Microbiol 2018; 9:1806.

35. Frouin E, Guillot B, Larrieux $M$, et al. Cutaneous epithelial tumors induced by vemurafenib involve the MAPK and Pi3KCA pathways but not HPV nor HPyV viral infection. PLoS One 2014; 9(10):e110478.

36. Dupin N, Deleuze J. Kaposi sarcoma and HHV-8: a model of cutaneous cancer in immunosuppressed patients. Rev Prat 2014; 64(3):311-316.

37. Patel A, Bishburg E, Zucker M, Tsang P, Nagarakanti S, Sabnani I. Concomitant Kaposi sarcoma and multicentric Castleman's disease in a heart transplant recipient. Heart Lung 2014; 43(6):506-509.

38. Le J. Oncogenic Y Herpesviruses EBV and HHV8 in Kidney Transplantation. Semin Nephrol 2016; 36(5):362-371.

39. Murahwa AT, Muchemwa FC, Duri K, et al. Presence of Betapapillomavirus in Kaposi sarcoma lesions. J Med Virol 2014; 86(9):15561559.

40. Murakami I, Matsushita M, Iwasaki $T$, et al. High viral load of Merkel cell polyomavirus DNA sequences in Langerhans cell sarcoma tissues. Infect Agent Cancer 2014; 9:15.

41. Binois R, Nadal M, Esteve E, et al. Cutaneous Kaposi sarcoma during treatment with superpotent topical steroids and methotrexate for bullous pemphigoid: three cases. Eur $J$ Dermatol 2017; 27(4):369-374.

42. Nakao R, Sakashita $A$, Omoto $A$, et al. Primary intra-aortic Epstein-Barr virus-positive large bcell lymphoma presenting as aortic mural thrombosis: an entity distinct from intravascular large B-cell lymphoma. Int J Surg Pathol 2017; 25(8):727-731.

43. Ikebe $T$, Sasaki $H$, Saburi $Y$, Ogata M. Bilateral psoas muscle lymphoma: an unusual 
presentation of EBV-positive diffuse large Bcell lymphoma of the elderly. Int $\mathrm{J}$ Hematol 2015; 102(5):509-510.

44. Montero Pérez I, Rodríguez-Pazos L, ÁlvarezPérez A, Ferreirós MM, Aliste C, SuarezPeñaranda JM, Toribio J. Kaposi sarcoma following postmastectomy lymphedema. $J$ Cutan Pathol 2015; 42(11):889-893.

45. Weiss RA. Tumour-inducing viruses. Br J Hosp Med (Lond) 2016; 77(10):565-568.

46. Petrosky E, Bocchini JA Jr, Hariri S. Centers for Disease Control and Prevention (CDC). Use of 9-valent human papillomavirus (HPV) vaccine: updated HPV vaccination recommendations of the advisory committee on immunization practices. MMWR Morb Mortal Wkly Rep 2015; 64(11):300-304.

47. Shen KY, Chang LS, Leng CH, Liu SJ. Selfadjuvanting lipoimmunogens for therapeutic HPV vaccine development: potential clinical impact. Expert Rev Vaccines 2015; 14(3):383394.

48. Vinzón SE, Rösl F. HPV vaccination for prevention of skin cancer. Hum Vaccin Immunother 2015; 11(2):353-357.

49. Tumban E, Peabody J, Peabody DS, Chackerian B. A pan-HPV vaccine based on bacteriophage PP7 VLPs displaying broadly cross-neutralizing epitopes from the HPV minor capsid protein, L2. PLoS One 2011; 6(8):e23310.

50. Chiocca EA, Rabkin SD. Oncolytic viruses and their application to cancer immunotherapy. Cancer Immunol Res 2014; 2(4):295-300.
51. Buijs PR, Verhagen $\mathrm{JH}$, van Eijck $\mathrm{CH}$, van den Hoogen BG. Oncolytic viruses: From bench to bedside with a focus on safety. Hum Vaccin Immunother 2015; 11(7):1573-1584.

52. Kohlhapp FJ, Kaufman HL. Molecular Pathways: Mechanism of action for Talimogene Laherparepvec, a new oncolytic virus Immunotherapy. Clin Cancer Res 2016; 22(5):1048-1054.

53. Killock D. Skin cancer: T-VEC oncolytic viral therapy shows promise in melanoma. Nat Rev Clin Oncol 2015; 12(8):438.

54. Andtbacka $\mathrm{RH}$, Kaufman $\mathrm{HL}$, Collichio $\mathrm{F}$. Talimogene Laherparepvec Improves durable response rate in patients with advanced melanoma. J Clin Oncol 2015; 33(25):27802788.

55. D'Angelo SP, Russell J, Lebbé C. Efficacy and safety of first-line Avelumab treatment in patients with stage IV metastatic Merkel cell carcinoma: A preplanned interim analysis of a clinical trial. JAMA Oncol 2018; 4(9): e180077.

56. Colunga $A$, Pulliam $T$, Nghiem $P$. Merkel cell carcinoma in the age of immunotherapy: facts and hopes. Clin Cancer Res 2018; 24(9):20352043.

57. Harms PW, Patel RM, Verhaegen ME, et al. Distinct gene expression profiles of viral- and nonviral-associated Merkel cell carcinoma revealed by transcriptome analysis. $J$ Invest Dermatol 2013; 133(4):936-945.

58. Nardi V, Song Y, Santamaria-Barria JA, et al. Activation of PI3K signaling in Merkel cell carcinoma. Clin Cancer Res 2012; 18(5):12271236. 